\title{
CYLINDER SEALS IN THE COLLECTIONS OF IZIKO MUSEUMS OF SOUTH AFRICA IN CAPE TOWN AND THE DEPARTMENT OF ANCIENT STUDIES OF STELLENBOSCH UNIVERSITY ${ }^{1}$
}

\author{
R Mvan Dijk-Coombes (Stellenbosch University)
}

\begin{abstract}
This paper studies the cylinder seals in the collections of Iziko Museums of South Africa in Cape Town and the Department of Ancient Studies of Stellenbosch University. The individual seals are described and there is an iconographic analysis of the scenes and motifs depicted on each seal, with comparisons to other artefacts. These seals date from the Early Dynastic period until the Persian period (ca. 3100-332 BC) and represent motifs such as deities, mythological beings and the 'master of animals', and scenes such as the contest scene and presentation scene.
\end{abstract}

\section{Introduction}

Thousands of cylinder seals ${ }^{2}$ are kept in museums across the world with artefacts from the ancient Near East. Many of these collections of cylinder seals have been published, such as those in the Yale Babylonian Collection in New Haven, Connecticut (Buchanan 1981), and those in the British Museum in London (Wiseman 1962; Collon 1982, 1986, 2001; Merrillees 2005). A handful of cylinder seals are also kept in collections in the Republic of South Africa. These collections of Ancient Near Eastern artefacts are in dire need of proper study and cataloguing. ${ }^{3}$

1 This paper was written within the framework of a Consolidoc Fellowship of Stellenbosch University. I am especially grateful to Izak Cornelius for his extensive support and supervision. I would also like to thank Iziko Museums of South Africa in Cape Town (Esther Esmyol) and the Department of Ancient Studies at Stellenbosch University for granting me permission to study and make impressions of the cylinder seals as well as to publish these seals. My thanks also to Rodrigo Cabrera Pertusatti for the translation and commentary of the inscription on Iziko $1528 \mathrm{e}$, as well as to Manuel Molina who assisted him. For the use of the illustrations from Schroer \& Keel 2005, I thank S Schroer, and for the illustrations from Winter 1983 and Keel-Leu \& Teissier 2004, I thank F Lippke (C) Stiftung Bibel+Orient Freiburg CH.

2 A cylinder seal is a small cylindrical object upon which images and inscriptions are carved so that they leave an impression behind when rolled across a surface of wet clay. Such seals functioned as markers of ownership or authenticity and were used to seal clay tablets with cuneiform inscriptions, containers, as well as doors. Seals are the most common source for pictorial representation in the ancient Near East. For more on cylinder seals in general, see Collon 2005.

3 Some of these objects have been published, for example Cornelius \& Boshoff 2002, Cornelius 2005, 2007, and Graham 2016. 
The purpose of this study is to publish the cylinder seals in the collections of Iziko Museums of South Africa in Cape Town and of the Department of Ancient Studies of Stellenbosch University.

There are five cylinder seals in the Cape Town collection, all of which are Ex-Levis Collection. These have been published previously in the South African Museum's Catalogue of the De Pass Collection (1934:18), but the descriptions of the iconography of these cylinders need revision. Impressions of these cylinder seals were made on the $31^{\text {st }}$ July 2013 at the Social History Building of Iziko Museums of South Africa in Cape Town.

There are six cylinder seals in the Stellenbosch collection; all were purchased by the late Professor Schroeder of the Department of Fine Arts at Stellenbosch University and were originally kept in the Department of Fine Arts of Stellenbosch University until they were donated to the Department of Ancient Studies of Stellenbosch University. Impressions of these cylinder seals were made on the $18^{\text {th }}$ July 2013 at the Department of Ancient Studies of Stellenbosch University.

The impressions of the cylinder seals will be presented as follows:

- Collection Number

- Date $^{4}$

- $\quad$ Material, size in centimetres, height then diameter

- Provenance (if known)

- Previous descriptions of the iconography (where relevant)

- Description. The impressions are described from left to right. Small objects (in the field) are listed from left to right and from top to bottom.

- Discussion and comparisons, including motifs and scenes

\section{Mesopotamian timeline}

Uruk Period

Jemdet Nasr Period

Early Dynastic Period

Akkadian Period

Neo-Sumerian Period ca. $4000-3100 \mathrm{BC}$

ca. 3100-2900 BC

ca. 2900-2334 BC

ca. 2334-2193 BC

ca. 2112-2004 BC

See the Mesopotamian timeline below. 
Isin-Larsa Period

Old Assyrian Period

Old Babylonian Period

Kassite (Middle Babylonian) Period

Middle Assyrian Period

Neo-Assyrian Period

Neo-Babylonian Period

Persian Period
ca. $2025-1887 \mathrm{BC}$
ca. $1920-1400 \mathrm{BC}$
ca. $1800-1595 \mathrm{BC}$
ca. $1475-1155 \mathrm{BC}$
ca. $1400-1050 \mathrm{BC}$
934-610 BC
626-539 BC
ca. $500-332 \mathrm{BC}$

\section{Cylinder seals of Iziko Museums of South Africa in the Cape Town collection}

\section{8a [Figure 1] ${ }^{5}$}

Old Babylonian, ca. 1800-1595 BC.

Haematite. $1,8 \times 1,0 \mathrm{~cm}$.

According to the Catalogue of the De Pass Collection (1934:18)

this seal was found at Uruk. Ex-Levis Collection.

Description in the Catalogue of the De Pass Collection (1934:18):

'figures of gods and worshippers. About 2000 BC'.

New description:

A bearded figure with a cap and a long garment raises his hand and faces a male god. A multiple-tiered horned headdress signifies his divinity. This god raises one leg in an ascending posture and wears a long garment and holds a rod with balls. A second god wears a multiple-tiered horned headdress and a long garment. A male figure in a shorter garment and a cap faces a goddess who wears a multiple-tiered horned headdress and a multiple-tiered dress and who raises both hands. A crook, a ball and staff with a pot, a seven-pointed star, and a fish are found in the field.

The horned headdress indicates divinity (Boehmer 1972-75a). For the god with the rod with balls, see Collon (1986:29) and van Buren (1945:153-155). This attribute is called the 'rod with balls' (Collon 1986:29; Porada 1948:141; van Buren 1945:153), the 'bouquet tree' (e.g. Buchanan 1981:362), or the 'Kugelbaum' or

All drawings of the seals in the collections of Iziko Museums of South Africa in Cape Town and the Department of Ancient Studies of Stellenbosch University, as well as

Figure 12 and Figure 15 are by the author. Figures 1-20 appear on pp. 14-19. 
'Kugelstab' (Collon 1980-1983:299). The earliest attestation of this symbol is during the Akkadian Period ca. 2334-2193 BC when it is found as a standard on the Naram-Sin Victory Stele (van Dijk 2016:245) [Figure 12]. A similar symbol dating to the Uruk and Jemdet Nasr period, ca. 4000-3100 BC and ca. 3100-2900 BC respectively, as for example that depicted on a vessel from Khafajeh today housed in the Iraq Museum in Baghdad [Figure 13], does not represent the same object. The ringed pole from the Uruk Period has a long shaft and an even number of rings. The symbol represents an architectural element formed by a reed bundle which was folded back on itself to form the rings. In comparison, the later symbol, as found on Iziko 1528a, has an odd number of solid balls or discs as one of these objects also surmounts the shaft. The shaft is shorter and the rod with balls is held by the god as a rod or sceptre. The Uruk Period ringed pole is found in the archaic Uruk script where it represents the sign NUN. Steinkeller (1998:88) identifies this sign as a symbol for the god Enki. This identification, however, is inappropriate for depictions of the rod with balls of later periods. The rod with balls may be associated with the god Adad, although an association with the god Šamaš appears more likely (Black \& Green 1992:155). However, for problems with this association, see Collon (1986:29). The symbol is found most commonly during 'the time between Ammiditana and Samsuditan' (van Buren 1945:155) during the Old Babylonian Period (ca. 1800-1595 BC).

The ball and staff with a pot is also known as the 'vessel and small vase' (van Buren 1945:138), the 'ball-and-staff' (Collon 1986:49) or the 'ball-staff' (Black \& Green 1992:30). For more on this symbol, see Collon (1986:49-51), Black \& Green (1992:30), and van Buren (1945:138-141). The pot or vase above the ball and staff is sometimes absent, although the two elements are more commonly represented together (Collon 1986:49).

The crook is found both held by a god and, as on Iziko 1528a, in the field. It is a symbol of the West-Semitic (Amorite) god Amurru or Martu (Kupper 1961). The fact that this symbol is not found on seals from the Isin-Larsa Period ca. 20251887 BC (Collon 1986:51) dates Iziko 1528a to the Old Babylonian Period. For more on the crook, see Black \& Green (1992:54), Collon (1986:51) and van Buren (1945:142-144). For the crook held by a god, see Collon (1986:28) and Colbow (2008).

Whereas the fish can be associated with Ea (Herles 2006:217; van Buren 1933:10) [Figure 14], the god of freshwater and wisdom, the star and fish appear to function here simply as filling motifs. See Collon (1986:48) for more on the star, and Unger (1957-1971), van Buren (1939:104-108) and Collon (1986:42) for more on the fish. 


\section{8b [Figure 2]}

Akkadian, ca. 2334-2193 BC.

Banded onyx/agate. $3,1(3,2) \times 2,0 \mathrm{~cm}$.

Ex-Levis Collection.

Description in the Catalogue of the De Pass Collection (1934:18): 'the mythical hero Merodach slaying the lion, and other figures. About 800-600 BC'.

Description on the museum card (1965): 'scenery from the Epos of Gilgamesh. They are combating lions and monsters. Also: Inkadoe, the hero with body and head of a man, but horns for ears, and with legs of a bull' ${ }^{6}$

Description in van Dijk (2016:172): 'a contest scene with three groupings; in two of these groupings a hero fights a lion, and in the third two human-headed bulls fight each other. A bull-man holds a standard'.

New description:

A contest scene with three groupings of combatants. Two human-headed bulls battle each other, and a lion and an en face nude hero with curly hair and a beard fight. A bull-man wearing a cap holds a standard. A nude hero with a cap fights a lion.

Previously also published by van Dijk (2016:172). The contest scene was one of the most commonly depicted types of scene during both the Early Dynastic Period (2900-2334 BC) (Collon 2005:27) and the Akkadian Period (2334-2193 BC) (Collon 1982:37). By the inclusion of antithetically placed human-headed bulls, the bull-man shown in profile, and the separation of the contestants into pairs of equally matched opponents, Iziko $1528 \mathrm{~b}$ can be dated to the early Akkadian period. See Boehmer (1965:3-460) and Collon (1982:37-67) for the development of the contest scene during the Akkadian period. ${ }^{7}$

The bull-man can be identified as such by the tail and the build of the lower body, but the depiction is unusual because the bull-man does not have horns, but wears a cap, and his legs end in feet and not hooves. For more on the bull-man,

6 The spelling of some of these names is now outdated. 'Merodach' is the old spelling for 'Marduk', and 'Inkadoe' for 'Enkidu'.

7 See Keel 1992:6-14 for the history and rejection of the contest scene as representing Gilgamesh and Enkidu. 
see Green (1993-1997:249-250) and Black \& Green (1992:48-49). The standard held by the bull-man is unique (van Dijk 2016:172). For the closest comparison, see British Museum BM 123568 [Figure 15] which shows an inverted star-spade / sun sign. The standard on Iziko 1528b, however, has no star, and a horizontal line is found directly below the point, and it therefore clearly does not represent an inverted star-spade / sun sign. The horizontal line may represent a plinth upon which the emblem of the standard rested, as, for example, on one of the standards on the Naram-Sin Victory Stele [Figure 12]. Perhaps instead of representing a standard, this object represents a spear, although during the late Early Dynastic and early Akkadian periods there are depictions of the bull-man holding a standard, but not a spear. See, for example, Boehmer (1965:Taf. VI Abb. 58, Taf. X Abb. 113 and Taf. XI Abb. 124) in which the bull-man holds a Bügelschaft standard. ${ }^{8}$

The en face nude hero with curly hair and a beard is unusual, but not unique, see, for example Louvre S 443 (Boehmer 1965: Taf 11.10), dating from the Early Dynastic III Period. The nude hero has been identified as the lahmu (e.g. Wiggermann 1983; 1992:164-166), although see Ellis (1995) for problems with this identification. For more on the nude hero, see Boehmer (1972-1975b: 293-302).

\section{8c [Figure 3]}

Old Babylonian, ca. 1800-1595 BC.

Crystal Quartz / Rock Crystal. 2,4 x 1,1 cm.

Ex-Levis Collection.

Description in the Catalogue of the De Pass Collection (1934:18): 'four human figures, a mythical animal and symbols. About 2000 BC'.

Description on the museum card (1965): 'Two long-robed figures standing face to face and two short-dressed figures bringing offerings. These figures are standing in opposite directions'.

New description:

Two groupings of figures, one of which is inverted. In the first grouping, two male figures in short garments face the left and each holds a vessel in the right hand. In the second grouping, two male figures face each other. The first wears a long garment and raises one arm while resting the elbow in

8 A Bügelschaft is a standard with a circular or semi-circular attachment at the side of the shaft. 
the other hand, the second wears a multiple-tiered garment and raises one arm. A ball staff with a vessel, a crescent, and a monkey are displayed in the field. The ball staff with vessel is aligned the same way as the first grouping, while the crescent and monkey are aligned with the second grouping.

Inversion is unusual, but it is not unique. Collon (1986:74) suggests that inversion signifies death. This may apply to some instances of inversion, such as where animals are displayed inverted in contest scenes, for example on the cylinder seal (Metropolitan Museum 55.65.4) from the Early Dynastic Period ca. 2900-2334 BC (Crawford, Harper, White Muscarella \& Bodenstein 1966:9, Fig. 10). In this instance, the inverted depiction of the bull could be interpreted to indicate that the bull had died. However, on Iziko 1528c and the contemporary Old Babylonian seal Marcopoli 118 (Teissier 1984:141, Cat. No. 118), the inversion rather seems to demarcate two separate groupings or scenes.

The monkey has also been identified as a mongoose (for example, Buchanan 1981:passim and Porada 1948:passim), but by comparison with an Old Babylonian terracotta disc carved in relief IM 32062 (Winter 1983: Abb. 256) [Figure 16] depicting dancers, musicians and monkeys, the animal can be identified as a monkey. The monkey is found on Isin-Larsa and early Old Babylonian seals, 'but it is not generally found on seals of post-Hammurabi date' (Collon 1986:46). For more on the portrayal of the monkey in Mesopotamian art, see also Hilzheimer (1928) and van Buren (1939:22-24).

According to the motifs included on Iziko $1528 \mathrm{c}$, it can be dated to early in the Old Babylonian Period.

\section{8d (Figure 4)}

Neo-Assyrian, 934-610 BC.

Agate. 2,2 x $1,2 \mathrm{~cm}$.

Ex-Levis Collection.

Description in the Catalogue of the De Pass Collection (1934:18): 'mythical human and animal figures. About 800 BC'.

Description on the museum card (1965): 'A four-winged human figure holds a horned animal at each side of a symbolic tree'.

New description:

An antithetical group consisting of a hero with four wings who faces right and stands in the 'master of the animals' pose between two horned animals. A tree (?) acts as a terminal to the scene. In the field is a rhomb. 
The style, known as the 'cut-and-drilled style' (Collon 2001:166), and subject matter date Iziko $1528 \mathrm{~d}$ to the Neo-Assyrian Period. For a similar subject, see Collon (2001:Plates XXIX - XXXII; see especially Plate XXXI for a similar style.) For more on the 'master of the animals' motif, see Calmeyer (19721975:334-335), Keel (1978:86-125) and Lang (2002:100-106). See also Collon (2001:165-167) where the subject is described as a 'three-figure contest'. The rhomb appears as a symbol from the Uruk Period until the Neo-Assyrian Period $c a$. 4000-610 BC (Black \& Green 1992:153). It appears to have been an apotropaic symbol, but does not appear to be associated with a specific deity (van Buren 1945:117). For the rhomb see Collon (2001:14-15), Black \& Green (1992:153) and van Buren (1945:115-119).

\section{8e [Figure 5]}

Neo-Sumerian / Old Babylonian, ca. 2112-1595 BC.

Black steatite / Slate. 3,0 x 1,4-1,5 cm (slightly concave).

Ex-Levis Collection.

Description in the Catalogue of the De Pass Collection (1934:18): 'two columns of cuneiform writing and two worshippers before a seated goddess. About 2000 BC'.

New description:

A presentation scene. A male figure is led by another male figure towards a seated bearded male figure. The first figure wears a cap and a long robe and has his right hand raised, and has no feet. The second figure wears a cap and a long garment. He holds the left hand of the first figure with his right hand. He raises his left hand towards the seated figure who also wears a long garment and a cap and raises his right hand at the approaching pair. In the field above the seated figure is a crescent. Cuneiform inscription.

The presentation scene was the most commonly depicted type of scene from the Neo-Sumerian Period until the Old Babylonian Period (ca. 2112-1595 BC). See Haussperger (1991) for a full discussion on presentation scenes from the Akkadian Period until the end of the Old Babylonian Period. The seated figure cannot represent a goddess, as there are no indicators of divinity, as for example the horned headdress, and the figure is bearded and must therefore be male. Winter (1986:255) identifies seated figures with rounded caps in Neo-Sumerian presentation scenes as rulers, and Andrae (1933:18) describes such figures as deified kings. In this case then, the scene can be described as a royal presentation 
scene. For more on royal presentation scenes on Neo-Sumerian seals, see Winter (1986) and Fischer (1997:130-134).

Based on its iconography, Iziko $1528 \mathrm{e}$ could be dated to the Neo-Sumerian Period ca. 2112-2004 BC or to the Isin-Larsa ca. 2025-1887 BC / Old Babylonian Period $c a$. 1800-1595 BC. The inscription does not clarify the matter, because according to the paleography of the inscription, Iziko $1528 \mathrm{e}$ could date from either the Neo-Sumerian or Old Babylonian Period. The onomastics are Semitic, but this does not exclude a Neo-Sumerian date. The inscription reads 'DINGIR. ŠU.KAK.HAR dumu AN.MUG', or 'DINGIR.ŠU.KAK.HAR son of AN.MUG'.

The first name DINGIR.ŠU.KAK.HAR may also be read as $\breve{S}$ - ${ }^{d}$ kak-kam (Dr. M Molina, personal correspondence). Curiously, there are two names with divine determinative $\{\mathrm{d}\}$. The translation could therefore also be 'Šu. ${ }^{\mathrm{d}} \mathrm{Kak}$-har son of AN.MUG'. Additionally, 'AN.MUG' could be read as 'DINGIR.MUG'. None of these names are known from other literature.

\section{Stellenbosch University seals}

\section{KG/VN/2 [Figure 6]}

Neo-Assyrian, 934-610 BC.

Chalcedony (agate) consisting of white and brown layers in a concentric pattern ( $R D$ 2,55). 2,3 x 0,6/1,2 cm (significant portion of lower half missing).

Unknown provenance, purchased by the late Professor Schroeder of the Department of Fine Arts at Stellenbosch University.

Description by Cornelius (2009:25): 'an encircled goddess with a headdress with a star on it ... facing a god in a winged-disk supported by winged bull-like beings and two worshippers - the one with an animal'.

New description:

A worship scene. A goddess in nimbus facing right, a hero with four wings and the lower body of an animal facing right and holding in upraised hands a god in a winged disc, two male figures facing left, the first raises his arm towards his face, the second holds a horned animal in one arm and a plant in the other hand.

Previously published by Cornelius (2009:25; 36, Fig. 14), who identifies the goddess in the nimbus as Ištar [Figure 17]. The hero holding the winged disc may have the lower limbs of a bull and therefore represent a bull-man, a figure 
known to support the winged disc of Šamaš, as for example on the Neo-Assyrian cylinder seal BM 102965 (Collon 2001:Plate XVI.210) [Figure 18]. The bull-man, however, is not usually depicted with wings. The scorpion-man is also sometimes depicted holding the winged disc (Collon 2001:Plate XVI.211), and was depicted with or without wings (Green 1993-1997:250) [Figure 19]. For an example of the scorpion-man with wings, see the Assyrian relief AO 19850 (see Meuszyński 1976: Plate XIV for a drawing of this relief). This suggests that the being holding the winged disc on $\mathrm{KG} / \mathrm{VN} / 2$ is a scorpion-man rather than a bull-man. In relation to this, on $\mathrm{KG} / \mathrm{VN} / 2$ a god is depicted within the winged disc, and on some Neo-Assyrian winged discs, like that depicted on BM 102965, two heads on the tips of the wings faced this central deity, and Black \& Green (1992:186) suggest that those heads may belong to scorpion-people.

KG/VN/3 [Figure 7]

Persian, $c a .500 \mathrm{BC}$.

Orange-brown stone. 2,6 x 1,2. Worn.

Unknown provenance, purchased by the late Professor Schroeder of the Department of Fine Arts at Stellenbosch University.

A figure acting as the 'master of the animals' holds two winged animals by their forelimbs. A plant acts as a terminal to the scene.

According to the subject matter and style this cylinder seal can be dated to the Persian Period. See Garrison \& Root (2001:121-148; Plates 29c-e; 32-40) for comparisons.

\section{KG/VN/4 [Figure 8]}

Late Early Dynastic II, ca. 2750-2600 BC or early Early Dynastic III, ca. 2600-2350 BC.

Translucent whitish stone. $2,6 \times 1,4$.

Unknown provenance, purchased by the late Professor Schroeder of the Department of Fine Arts at Stellenbosch University.

Contest scene. A male figure with spiky hair who is naked, except for a belt, faces right and stands between a bull and an ibex (?), a thinner male figure, also with spiky hair and naked, except for a belt, who faces right, two crossed animals (a bull and a lion?), a naked figure with an indistinct head facing left, a horned animal. In the field (below right), a scorpion. 
For the figure with spiky hair, see Aleppo 2478 (Boehmer 1965:Taf. II.14a), dating to what Boehmer calls the 'Akkadisch I a 'sumerische' Gruppe'. According to Boehmer (1972-1975b:296), the hero with the 'aufrecht stehenden Haar' is found during the start of the Early Dynastic III Period. KG/VN/4 is similar in style and subject to Martin's Crossed Style, dating to the Early Dynastic II Period, which comprises of 'one, long frieze ... accomplished with the extensive use of crossed animals' (Martin 1988:74). KG/VN/4 can therefore be dated to either the late Early Dynastic II Period or the early Early Dynastic III Period.

On Kassite Period (ca. 1475-1155 BC) kudurrus ${ }^{9}$ the scorpion was the symbol of the goddess Išhara (Seidl 1989:157), but this appears to be the earliest attestation of the scorpion as a symbol of a deity. For more on the scorpion in Mesopotamian art, see van Buren (1937-39; 1939:110-112), Ornan (2005: 159-160), Black \& Green (1992:160-161) and Pientka-Hinz (2009-2011:579). For more on Išhara see Prechel (1996; 2009), Archi (2002), Herles (2006:223-225), Lambert (1976-1980), Leick (1998:94-95) and Black \& Green (1992:110).

\section{KG/VN/5 [Figure 9]}

First Millennium BC.

Black stone. 2,6 x 1,3 cm. Worn.

Unknown provenance, purchased by the late Professor Schroeder of the Department of Fine Arts at Stellenbosch University.
A 'master of the animals' figure between two lions (?). Cuneiform inscription.

Because KG/VN/5 is so worn it is difficult to accurately date it. The 'master of the animals' motif is known from the Uruk Period. The iconography of KG/VN/5 is not consistent with other examples of the 'master of the animals' from the third millennium. It appears rather to date to the first millennium.

Because of the wear on $\mathrm{KG} / \mathrm{VN} / 5$, the inscription is also difficult to translate.

\section{KG/VN/6 [Figure 10]}

Neo-Assyrian, 934-610 BC or Neo-Babylonian, 626-539 BC.

Pale stone. 2, x 1,2 cm. Very fine engraving in the cut style. Minor chipping.

9 A kudurru is a stone boulder or stele which documented a land grant from the king. They are important for iconographic studies because the symbols of the deities called to witness the transaction are depicted on the kudurru, and these are often captioned, allowing the identification of symbols of deities. For a full discussion on kudurrus and the symbols found on kudurrus, see Seidl 1989. See also Seidl 1980-1983. 
Unknown provenance, purchased by the late Professor Schroeder of the Department of Fine Arts at Stellenbosch University.

A bird-griffin and a lion-griffin stand on hind legs and face towards the right. In the field, a six-pointed star is found above the birdgriffin and the remains of a crescent above the lion-griffin.

According to the subject matter and style, KG/VN/6 is Neo-Assyrian or NeoBabylonian. For the same subject with slightly different style, see BM 119328 (Collon 2001:Plate V.64) and Morgan Seal 746 (Porada 1948: Plate CXI 746). BM 119328 was cut and only half of the star above the bird-griffin is extant, while above the lion-griffin [Figure 20] is the lower part of a crescent (Collon 2001:52). KG/VN/6 has a chip above the lion-griffin, but comparison to BM 119328 and Morgan Seal 746, allows for the identification of the remains of a crescent on either side of the chip.

\section{KG/VN/7 [Figure 11]}

Late Bronze Age Levant (?), ca. 1500-1000 BC.

Dark stone. 1,8-1,9 (seal cut slightly skew) x 1,6 cm.

Unknown provenance, purchased by the late Professor Schroeder of the Department of Fine Arts at Stellenbosch University

Presentation scene? A figure stands with both arms down at the side (holding object in left hand?), a second figure faces the first and raises one hand to the face, a third figure wears a headdress and faces right, raising one arm to a fourth figure who is seated. This seated figure also raises one hand to the face. Terminal, a vertical line. In the field, ball-staff and crescent on pole (?).

According to the style in which the figures are represented $\mathrm{KG} / \mathrm{VN} / 7$ can be identified as a second millennium cylinder seal from the Levant. On a cylinder seal from Alalakh (Collon 2005:71 Cat. No. 306), dating to the second half of the second millennium, human figures are depicted in a similar manner to KG/VN/7, and the Syrian Seal Marcopoli 367 (Teissier 1984:205, Cat. No. 367), dating to the early second millennium, contains a depiction of a seated figure similar to that on $\mathrm{KG} / \mathrm{VN} / 7$.

\section{Conclusions}

The seals in the collections of the Iziko Museums of South Africa in Cape Town and the Department of Ancient Studies of Stellenbosch University date from 
various periods and depict a variety of motifs. Unfortunately the exact origins of these seals are uncertain, but the possible dates can be established by comparison to artefacts of known provenance.

The oldest cylinder seal dates from the Early Dynastic Period at the start of the third millennium $\mathrm{BC}$, while the youngest dates from the Persian Period in the second half of the first millennium BC. Four of the five seals from the collection of the Iziko Museum of South Africa, 1528a, 1528b, 1528c and 1528e, date from the end of the third millennium $\mathrm{BC}$ to the beginning of the second millennium $\mathrm{BC}$, while the fifth seal, 1528d, dates to the first millennium BC. Four of the seals from the Stellenbosch collection, $\mathrm{KG} / \mathrm{VN} / 2, \mathrm{KG} / \mathrm{VN} / 3, \mathrm{KG} / \mathrm{VN} / 5$ and $\mathrm{KG} / \mathrm{VN} / 6$, date to the first millennium $\mathrm{BC}$, while a fifth, $\mathrm{KG} / \mathrm{VN} / 4$, dates to the first half of the third millennium $\mathrm{BC}$ and the sixth, $\mathrm{KG} / \mathrm{VN} / 7$, to the second half of the second millennium $\mathrm{BC}$.

The contest scene was one of the most commonly depicted types of scene during the Early Dynastic and the Akkadian periods. This type of scene is represented twice, on $1528 \mathrm{~b}$ and on $\mathrm{KG} / \mathrm{VN} / 4$. Seal $1528 \mathrm{~b}$ dates to the Akkadian Period, while KG/VN/4 dates to the Early Dynastic Period.

The most commonly depicted type of scene from the Neo-Sumerian Period until the Old Babylonian Period was the presentation scene. This type of scene is represented on 1528e, which dates to the Neo-Sumerian or Old Babylonian Period, and possibly on $\mathrm{KG} / \mathrm{VN} / 7$, dating to the second half of the second millennium BC. This latter seal is also the only example discussed which does not appear to originate from Mesopotamia, but from the Levant.

There are three scenes with the 'master of the animals' motif, all of which date to the first millennium $\mathrm{BC}$. Two of these, $1528 \mathrm{~d}$ and $\mathrm{KG} / \mathrm{VN} / 5$, are NeoAssyrian or Neo-Babylonian, while KG/VN/3 dates from the Persian Period. Scenes of a mythological nature, in the sense that mythic or supernatural figures act as participants in the scenes, and not that the scene represents a specific mythological setting, are represented on 1528a, in which three deities appear, and on $\mathrm{KG} / \mathrm{VN} / 2$, which represents a worship scene with deities. $\mathrm{KG} / \mathrm{VN} / 6$ also represents a mythological scene in the sense that two mythological or supernatural creatures - a bird-griffon and a lion-griffon - chase each other. Seal 1528c may represent some kind of ritual scene. There are no attributes to identify any of the figures as deities.

These cylinder seals should be added to the already large collection of published seals so that they can be compared to other examples and so that further insights can be gained. 
Figures 1-20
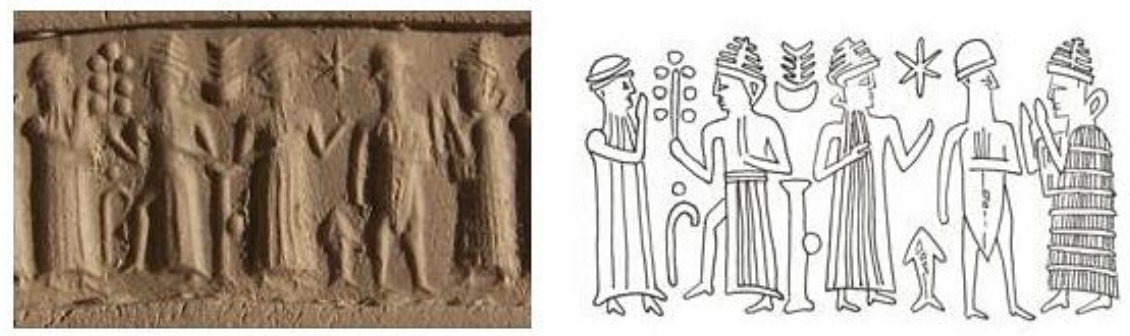

Figure 1: 1528a
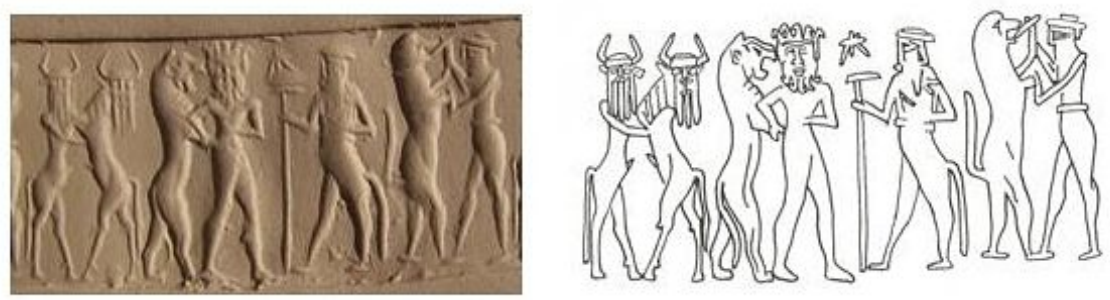

Figure 2: 1528b
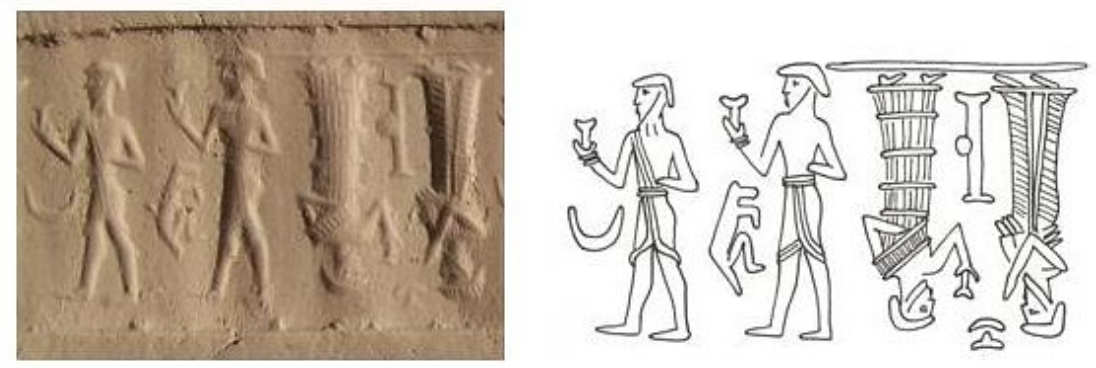

Figure 3: 1528c 

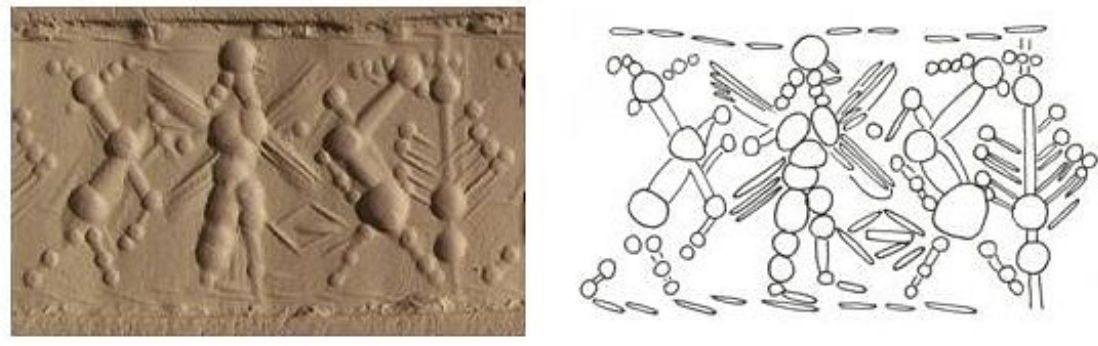

Figure 4: 1528d
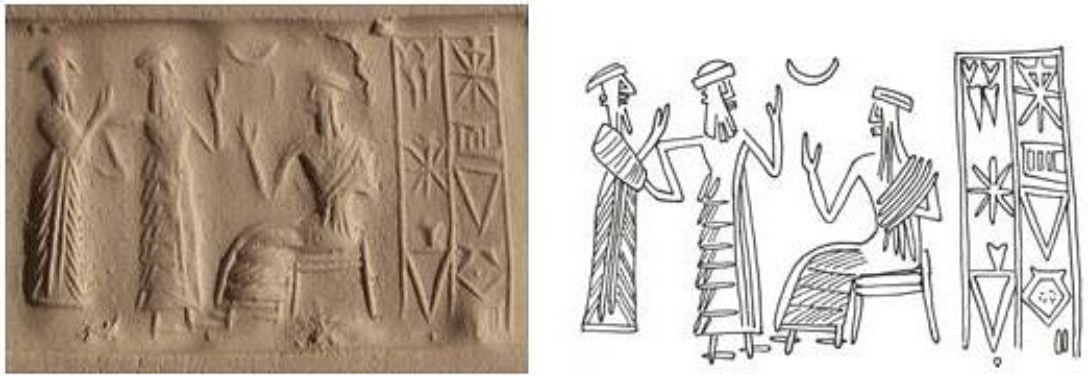

Figure 5: 1528e
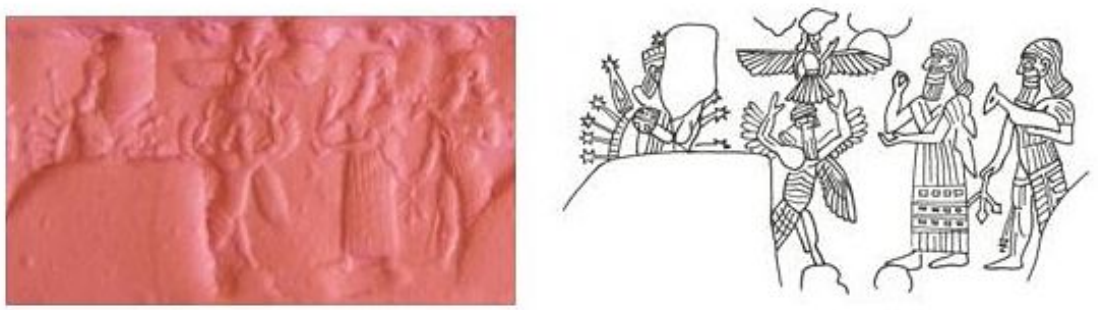

Figure 6: KG/VN/2 

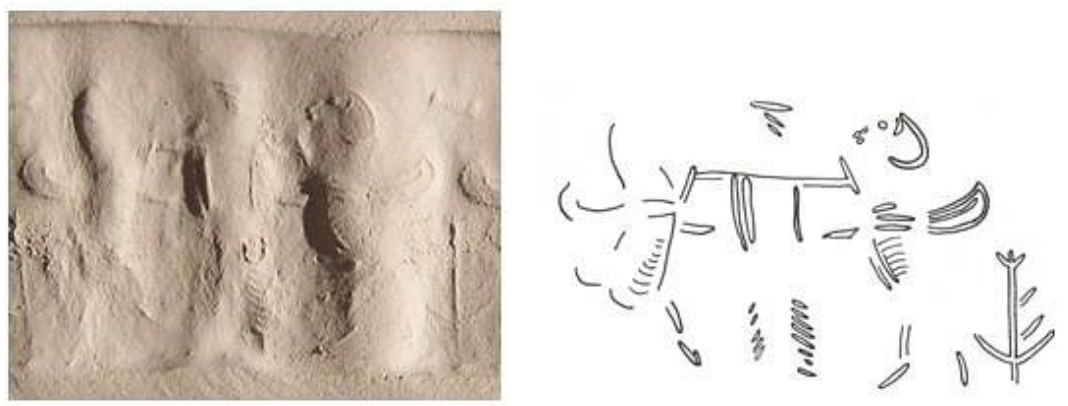

Figure 7: KG/VN/3
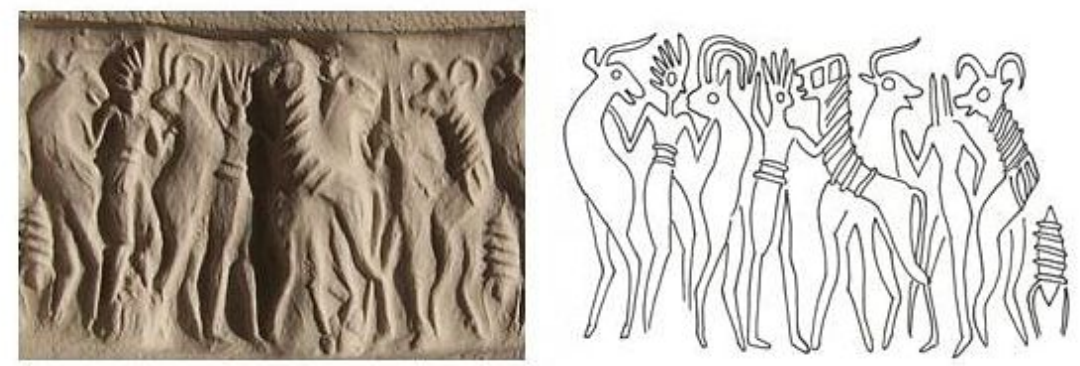

Figure 8: KG/VN/4
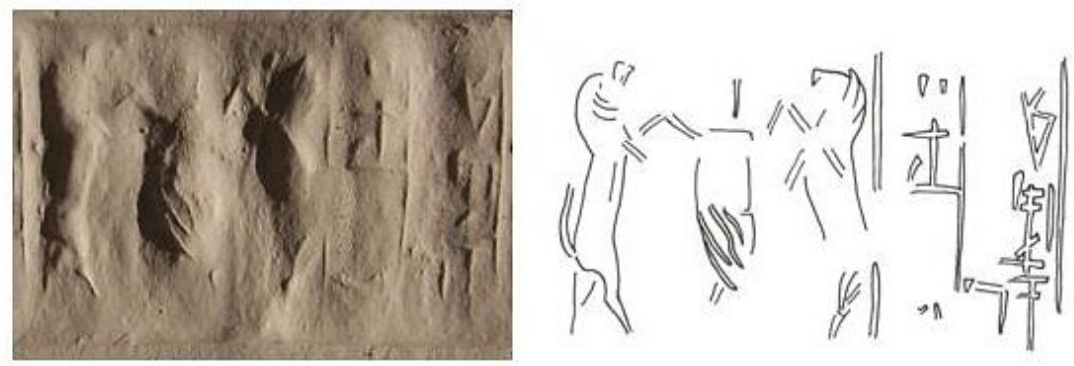

Plate 9: KG/VN/5 

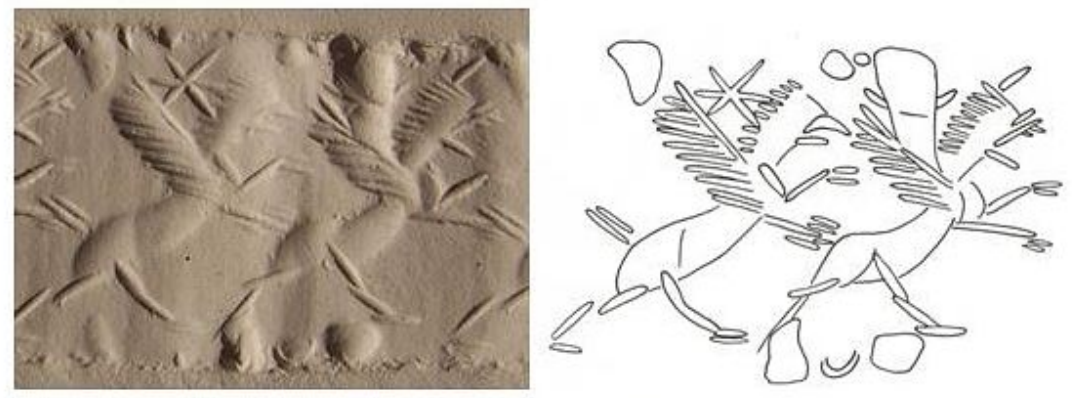

Figure 10: KG/VN/6
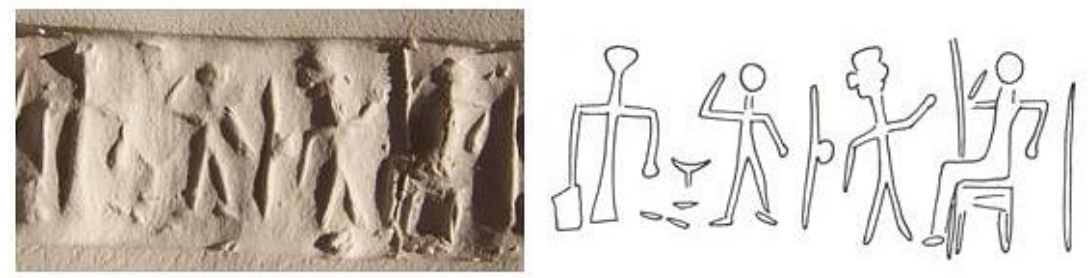

Figure 11: KG/VN/7 


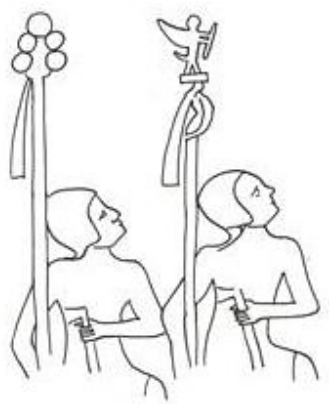

Figure 12: The standards on the Victory of Naram-Sin.

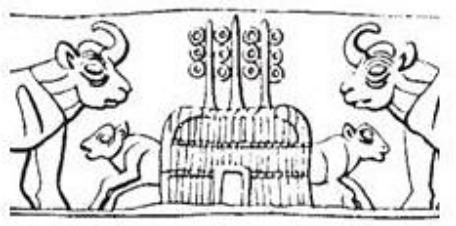

Figure 13: Vessel from Khafajer (Schroer \& Keel 2005:289 Nr. 191 detail).

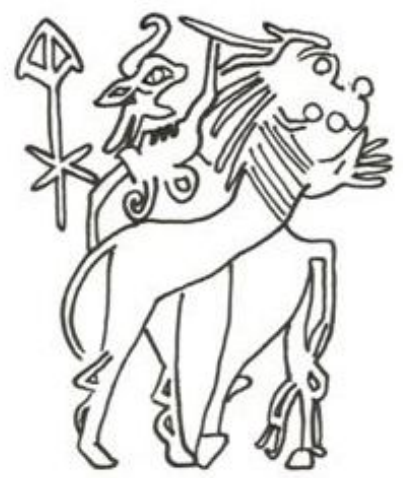

Figure 15: BM 123568 (detail)

Figure 14: Ea with streams of water 


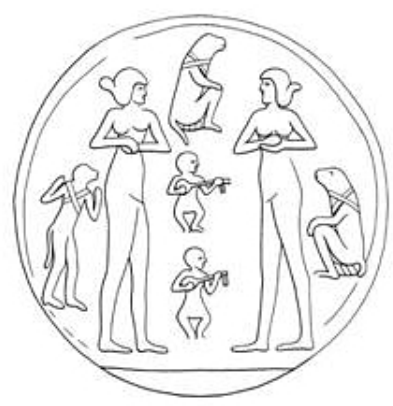

Figure 16: Old Babylonian disc (Winter 1983: Abb. 256).

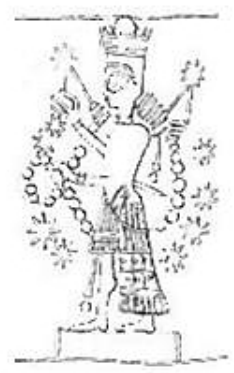

Figure 17: Ištar (Keel-Leu \& Teissier 2004:407 Nr. 237 detail).

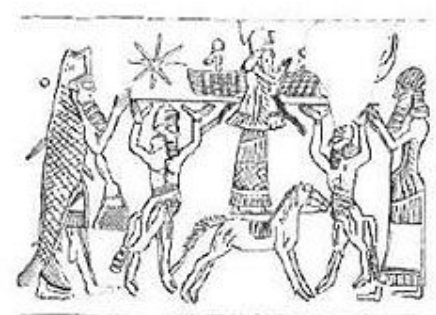

Figure 18: Bull-men (Keel-Leu \& Teissier 2004:407 Nr. 236).

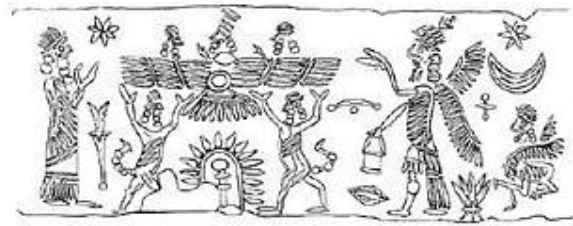

Figure 19: Scorpion-men (KeelLeu \& Teissier 2004:407 Nr. 235).

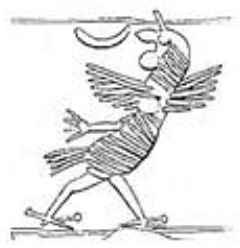

Figure 20: Griffon (Keel-Leu \& Teissier 2004:406: Nr. 226 detail). 


\section{BIBLIOGRAPHY}

Andrae, W 1933. Die Ionische Säule: Bauform oder Symbol? Verlag Studien zur Bauforschung 5. Berlin: Verlag für Kunstwissenschaft.

Archi, A 2002. Formation of the West Hurrian pantheon. In Aslihan Yener, K \& Hoffner, Jr. H A (eds.) 2002:21-33.

Aslihan Yener, K \& Hoffner, Jr., H A (eds.) 2002. Recent developments in Hittite archaeology and history. Papers in memory of Hans G Güterbock. Winona Lake: Eisenbrauns.

Black, J \& Green, A 1992. Gods, demons and symbols of ancient Mesopotamia. Austin: University of Texas Press.

Boehmer, R M 1965. Die Entwicklung der Glyptik während der Akkad-Zeit. Untersuchungen zur Assyriologie und Vorderasiatischen Archäologie 4. Berlin: Walter de Gruyter \& Co.

— 1972-75a. Hörnerkrone. RlA IV:431-434.

1972-75b. Held. B. In der Bildkunst. RlA IV:293-302.

Braun, J, Łyczkowska, K, Popko, M \& Steinkeller, P (eds.) 1998. Written on clay and stone: Ancient Near Eastern studies presented to Krystyna Szarzyńska on the occasion of her $80^{\text {th }}$ birthday. Warsaw: Agade.

Buchanan, B 1981. Early Near Eastern seals in the Yale Babylonian collection. New Haven \& London: Yale University Press.

Calmeyer, P 1972-1975. Herr der Tiere. RlA 4:334-335.

Colbow, G 2008. Amurru. In Eggler \& Uehlinger (eds.) 2009. Iconography of deities and demons in the ancient Near East.

http://www.religionswissenschaft.uzh.ch/idd/prepublications/e_idd_amurru. pdf accessed 8 February 2016.

Collon, D 1980-1983. Kugelbaum, Kugelstab. RlA 6:299.

— 1982. Catalogue of the Western Asiatic seals in the British Museum II: Akkadian, Post Akkadian, Ur III periods. London: British Museum.

1986. Catalogue of the Western Asiatic seals in the British Museum III: Isin-Larsa and Old Babylonian periods. London: British Museum.

2001. Catalogue of the Western Asiatic seals in the British Museum V: NeoAssyrian and Neo-Babylonian periods. London: British Museum.

— 2005. First impressions: Cylinder seals in the ancient Near East. London: British Museum Press.

Cornelius, I 2005. Van die Nyl tot Stellenbosch: Antieke Egiptiese voorwerpe in Stellenbosch. Akroterion 50:125-136.

2007. A horse figurine in Stellenbosch and the iconography and function of Palestinian horse figurines. Zeitschrift des Deutschen Palästina-Vereins 123:28-36, Tafel 4. 
Cornelius, I 2009. Aspects of the iconography of the warrior goddess Ishtar and ancient Near Eastern prophecies. In Nissinen, M \& Carter, C E (eds.) 2009:15-40.

Cornelius, I \& Boshoff, A 2002. The Egyptian collection in Iziko Museums of Cape Town, South Africa. In Eldamaty, M \& Trad, M (eds.) 2002:133-142.

Crawford, V E, Harper, P O, White Muscarella, O \& Bodenstein, B E (eds.) 1966. The Metropolitan Museum of Art guide to the collections: Ancient Near Eastern art. New York: The Metropolitan Museum of Art.

Eldamaty, M \& Trad, M (eds.) 2002. Egyptian museum. Collections around the world: Studies for the centennial of the Egyptian museum. Cairo: Supreme Council of Antiquities, American University in Cairo Press, Vol.1.

Eggler, J \& Uehlinger, C (eds.) 2009. Iconography of deities and demons in the ancient Near East, http://www.religionswissenschaft.uzh.ch/idd/ accessed 8 February 2016.

Ellis, R S 1995. The trouble with 'Hairies'. Iraq 57:159-165.

Fischer, C 1997. Siegelabrollungen im British Museum auf Ur-III-zeitlichen Texten aus der Provinz Lagaš. Baghdader Mitteilungen 28:97-183.

Garrison, M B \& Root, M C 2001. Seals on the Persepolis fortification tablets, Vol. I: Images of heroic encounter. Parts $1 \& 2$. OIP 117. Chicago: OIP.

Graham, S 2016. Classical antiquities in Durban: A study of two collections. Unpublished MA thesis in Ancient Cultures at Stellenbosch University, March 2016. Online at http://scholar.sun.ac.za/handle/10019.1/98747

Green, A 1993-1997. Mischwesen. B. Archäologie. Mesopotamien. RlA 8:246-264. Haussperger, M 1991. Die Einführungsszene: Entwicklung eines mesopotamischen Motivs von der altakkadischen bis zum Ende der altbabylonischen Zeit. München \& Wien: Profil Verlag.

Herles, M 2006. Götterdarstellungen Mesopotamiens in der 2. Hälfte des 2. Jahrtausends v. Chr. Das anthropomorphe Bild im Verhältnis zum Symbol. AOAT 329. Münster: Ugarit-Verlag.

Hilzheimer, F Affe. RlA 1:41-42.

Keel, O 1978. Jahwes Entgegnung an Ijob: Eine Deutung von Ijob 38-41 vor dem Hintergrund der zeitgenössischen Bildkunst. FRLANT 121. Göttingen: Vandenhoeck und Ruprecht.

— 1992. Das Recht der Bilder gesehen zu Werden. OBO 122. Fribourg: Academic Press.

Keel-Leu, H \& Teissier, B 2004. Die vorderasiatischen Rollsiegel der Sammlungen $<<$ Bibel + Orient $>>$ der Universität Freiburg Schweiz. The ancient Near Eastern cylinder seals of the Collections $<<$ Bibel + Orient $>>$ of the University of Fribourg. OBO 200. Fribourg/Göttingen: Fribourg Academic Press/Vandenhoeck \& Ruprecht. 
Kelly-Buccellati, M (ed.) 1986. Insight through images: Studies in honor of Edith Porada. Bibliotheca Mesopotamica 21. Malibu: Udena Publications.

Kupper, J-R 1961. L'iconographie du dieu Amurru dans la glyptique de la $I^{\text {re }}$ dynastie babylonienne. Brussels: Académie royale de Belgique.

Lambert, W G 1976-1980. Išhara. RlA 5:176-177.

Lang, B 2002. Jahwe, der biblische Gott: Ein Porträt. München: Verlag C H Beck. Leick, G 1998. A dictionary of Near Eastern mythology. London: Routledge.

Martin, H P 1988. Fara: A reconstruction of the ancient Mesopotamian city of Shuruppak. Birmingham: Chris Martin \& Associates.

Merrillees, P H 2005. Catalogue of Western Asiatic seals in the British Museum: Cylinder seals VI: Pre-Achaemenid and Achaemenid periods. London: The British Museum Press.

Meuszyński, J 1976. Neo-Assyrian reliefs from the central area of Nimrud citadel. Iraq 38/1:37-43.

Nissinen, M \& Carter, C E (eds.) 2009. Images and prophecy in the ancient Near Eastern Mediterranean. FRLANT 233. Göttingen: Vandenhoeck \& Ruprecht.

Ornan, T 2005. The triumph of the symbol: Pictorial representation of deities in Mesopotamia and the biblical image ban. OBO 213. Fribourg/Göttingen: Fribourg Academic Press/Vandenhoeck \& Ruprecht.

Pientka-Hinz, R 2009-2011. Skorpion. RlA 12:576-580.

Porada, E 1948. Corpus of ancient Near Eastern seals in North American collections: The Collection of the Pierpont Morgan Library. Vols $1 \& 2$. Washington DC: Pantheon Books Inc.

Prechel, D 1996. Die Göttin Išhara: Ein Beitrag zur altorientalischen Religionsgeschichte. ALASPM 11. Münster: Ugarit Verlag.

2009. Ishara. In Eggler \& Uehlinger (eds.),

http://www.religionswissenschaft.uzh.ch/idd/prepublications/e_idd_ishara. pdf accessed 8 February 2016.

Schroer, S \& Keel, O 2005. Die Ikonographie Palästinas/Israels und der Alte Orient (IPIAO). Eine Religionsgeschichte in Bildern. Band I. Vom ausgehenden Mesolithikum bis zur Frühbronzezeit. Freiburg: Academic Press Fribourg.

Seidl, U 1989. Die babylonischen Kudurrurreliefs: Symbole mesopotamischer Gottheiten. OBO 87. Fribourg/Göttingen: Fribourg Academic Press / Vandenhoeck \& Ruprecht.

— 1980-1983. Kudurru. B. Bildschmuck. RlA 6:275-277.

South African Museum. 1934. Catalogue of the De Pass Collection: Objects illustrating the arts of ancient civilizations: Egyptian, Greek, Chinese, Persian and others. Cape Town: South African Museum. 
Steinkeller, P 1998. Inanna's archaic symbol. In Braun, Łyczkowska, Popko \& Steinkeller (eds.) 1998:87-100.

Teissier, B 1984. Ancient Near Eastern cylinder seals from the Marcopoli Collection. Berkeley: University of California Press.

Unger, E Fisch als Symbol. RlA 3:67-68.

van Buren, E D 1933. The flowing vase and the god with streams. Berlin: Hans Schoetz \& Co.

— 1937-1939. The scorpion in Mesopotamian art and religion. AfO 12:1-28.

— 1939. The fauna of ancient Mesopotamia as represented in art. Analecta Orientalia 18. Rome: Pontificum Institutum Biblicum.

— 1945. Symbols of the gods in Mesopotamian art. Rome: Pontificum Institutum Biblicum.

van Dijk, R M 2016. The form, function and symbolism of standards in ancient Mesopotamia during the third and fourth millennia BCE: An iconographical study. Unpublished $\mathrm{PhD}$ dissertation in Ancient Cultures at Stellenbosch University, March 2016.

Available online at http://scholar.sun.ac.za/handle/10019.1/98400

Wiggermann, F A M 1983. Exit Talim! Studies in Babylonian demonology, I. JEOL 27:90-105.

Wiggermann, F A M 1992. Mesopotamian protective spirits: The ritual texts. Cuneiform Monographs I. Groningen: Styx.

Winter, I J 1986. The king and the cup: Iconography of the royal presentation scene on Ur III seals. In Kelly-Buccellati 1986:253-268.

Winter, U 1983. Frau und Göttin: Exegetische und ikonographische Studien zum wieblichenn Gottesbild im Alten Israel und in dessen Umwelt. OBO 53. Fribourg/Göttingen: Fribourg Academic Press/Vandenhoeck \& Ruprecht.

Wiseman, D J 1962. Catalogue of the Western Asiatic seals in the British Museum I: Cylinder seals: Uruk - Early Dynastic periods. London: British Museum.

\section{ABBREVIATIONS}

AfO Archiv für Orientforschung

AOAT Alter Orient und Altes Testament

FRLANT Forschungen zur Religion und Literatur des Alten und Neuen Testaments

JEOL Jaarbericht van het Voor-Aziatisch-Egyptisch-Gezelschap Ex Oriente Lux

OBO Oribis Biblicus et Orientalis

OIP Oriental Institute Publications

RlA Reallexikon der Assyriologie und vorderasiatischen Archäologie 